\title{
Failure to Form Staple
}

National Cancer Institute

\section{Source}

National Cancer Institute. Failure to Form Staple. NCI Thesaurus. Code C64328.

Problem associated with the device failing to connect tissue with a stapling device due to the staples not forming correctly. 